\title{
Pengembangan Desa Wisata Pentingsari, Kabupaten Sleman dalam Perspektif Partisipasi Masyarakat
}

\author{
Development of Pentingsari Tourism Village, Sleman District \\ on the Perspective of Community Participation
}

\author{
Dinar Wahyuni \\ hi_dins@yahoo.com \\ Pusat Penelitian Badan Keahlian DPR RI \\ Jl. Gatot Subroto, Senayan, Jakarta
}

\begin{abstract}
Naskah diterima: 28 September 2019 | Naskah direvisi: 7 November 2019 | Naskah diterbitkan: 29 Desember 2019
\end{abstract}
\begin{abstract}
Village tourism is one form of tourism that applies the concept of community empowerment so that community participation is the most important component in its development. This study aims to describe the development of the Pentingsari Tourism Village in the perspective of community participation. This research is descriptive with a qualitative approach. The results showed that the development of the Pentingsari Tourism Village received full support from the Pentingsari community and local government through its participation in tourism activities. At the planning and decisionmaking stages, the community participated from planning, socialization to community and village government, to making decisions about the formation of a tourism village. Community participation in the implementation phase is carried out by giving ideas, material, and being directly involved in every tourism village development activity and trying to create a tourism village that is ready to compete in the tourism industry. Participation in the stage of enjoying the results is shown by improving the living conditions of the Pentingsari community due to tourism activities. This means that the community enjoys the results of tourism, economically, socially, culturally, and environmentally. Furthermore, community participation in the evaluation phase was demonstrated through their involvement in regular meetings between village tourism managers, village government and local government.
\end{abstract}

Keywords: community participation, village development, tourism village

\begin{abstract}
Abstrak: Desa wisata merupakan salah satu bentuk wisata yang menerapkan konsep pemberdayaan masyarakat sehingga partisipasi masyarakat menjadi komponen terpenting dalam pengembangannya. Penelitian ini bertujuan untuk mendeskripsikan tentang pengembangan Desa Wisata Pentingsari dalam perspektif partisipasi masyarakat. Penelitian ini bersifat deskriptif dengan pendekatan kualitatif. Hasil penelitian menunjukkan bahwa pengembangan Desa Wisata Pentingsari mendapat dukungan penuh dari masyarakat Pentingsari dan pemerintah daerah melalui partisipasinya dalam kegiatan wisata. Pada tahap perencanaan dan pengambilan keputusan, masyarakat berpartisipasi mulai dari perencanaan, sosialisasi ke masyarakat dan pemerintah desa hingga pengambilan keputusan tentang pembentukan desa wisata. Partisipasi masyarakat dalam tahap implementasi dilakukan dengan memberikan pemikiran, materi, dan terlibat langsung dalam setiap kegiatan pengembangan desa wisata serta berupaya menciptakan desa wisata yang siap bersaing di industri pariwisata. Partisipasi dalam tahap menikmati hasil ditunjukkan dengan peningkatan kondisi kehidupan masyarakat Pentingsari akibat kegiatan wisata. Hal ini berarti bahwa masyarakat menikmati hasil dari kegiatan wisata baik secara ekonomi, sosial, budaya, dan lingkungan. Selanjutnya partisipasi masyarakat dalam tahap evaluasi ditunjukkan melalui keterlibatannya dalam pertemuan rutin antarpengelola desa wisata, pemerintah desa, dan pemerintah daerah setempat.
\end{abstract}

Kata kunci: partisipasi masyarakat, pengembangan desa, desa wisata 


\section{Pendahuluan}

Dalam satu dasawarsa terakhir ini, kontribusi sektor pariwisata terhadap penerimaan devisa negara terus meningkat. Kementerian Pariwisata mencatat penerimaan devisa negara dari sektor pariwisata di tahun 2014 US\$10,69 miliar dan tahun 2017 meningkat menjadi US\$16,10 miliar (Petriella, 2019). Peningkatan penerimaan devisa tersebut, didukung oleh kenaikan jumlah kunjungan wisatawan mancanegara (wisman) ke Indonesia. Badan Pusat Statistik (BPS) merilis jumlah kunjungan wisman ke Indonesia selama 2018 mencapai 15,81 juta kunjungan (BPS, 2019). Angka ini naik 12,58\% dibandingkan dengan jumlah kunjungan wisman pada periode yang sama tahun 2017 yang berjumlah 14,04 juta kunjungan (BPS, 2019).

Tabel 1. Penerimaan Devisa Negara dari Pariwisata dan Jumlah Kunjungan Wisman, Tahun 2014-2018

\begin{tabular}{ccc}
\hline Tahun & $\begin{array}{c}\text { Devisa } \\
\text { (US\$ Miliar) }\end{array}$ & $\begin{array}{c}\text { Jumlah } \\
\text { Kunjungan } \\
\text { Wisman (Juta) }\end{array}$ \\
\hline 2014 & 10,69 & 9,40 \\
2015 & 12,23 & 10,40 \\
2016 & 13,48 & 11,50 \\
2017 & 15,20 & 14,04 \\
2018 & 16,10 & 15,81 \\
\hline
\end{tabular}

Sumber: Diolah dari Novaria, 2018

Sejalan dengan peningkatan kontribusi pariwisata ke negara, serangkaian dampak negatif dari kegiatan pariwisata juga muncul. Penurunan kualitas lingkungan alam, sosial, dan budaya, terjadinya gap ekonomi antara pemilik modal dengan masyarakat setempat, dan marginalisasi potensi sosial ekonomi masyarakatnya ikut mewarnai perkembangan pariwisata. Penelitian I Putu Gede Parma memperlihatkan bahwa kondisi pariwisata saat ini semakin mendekati titik jenuh dengan produk wisata yang ditawarkan kepada wisatawan. Karena produk-produk tersebut lebih banyak memberikan dampak negatif terhadap lingkungan dibandingkan dampak positifnya. Lingkungan tereksplorasi secara berlebihan tanpa terukur dengan baik. Carrying capacity yang seharusnya menjadi indikator dalam pengembangan suatu objek pariwisata menjadi terabaikan (Parma, 2014: 45). Kondisi tersebut menumbuhkan kesadaran para pembuat kebijakan akan arti penting pariwisata yang lebih memperhatikan kelestarian lingkungan dan kesejahteraan masyarakat lokal.

Tren wisata yang cenderung bergeser dari wisata massal ke wisata kelompok kecil yang lebih menekankan interaksi dengan alam, budaya, dan kehidupan masyarakat semakin memengaruhi para pembuat kebijakan dalam membuat kebijakan terkait pariwisata. Ditambah lagi keluarnya Undang-Undang Nomor 6 Tahun 2014 tentang Desa yang memberikan kewenangan yang lebih besar bagi masyarakat di desa untuk membangun wilayahnya semakin mendorong pembuat kebijakan untuk memanfaatkan potensi sumber daya alam yang ada di desa untuk kegiatan pariwisata. Karena wisatajenis ini dipandang lebih memberikan dampak positif bagi masyarakat di sekitarnya dengan tetap menghargai lingkungan dan kebudayaan masyarakat lokal. Menurut Daldjoeni (1998, dalam Dinas Pariwisata DIY, 2014: 6), setiap desa memiliki geographical setting dan human effort yang berbeda-beda. Hal ini akan memengaruhi strategi masyarakat sebagai host community dalam memanfaatkan potensi yang ada untuk dikemas sebagai atraksi yang menarik bagi wisatawan.

Berangkat dari hal tersebut, pemerintah berupaya untuk mengembangkan desa wisata sebagai tempat tujuan wisata yang unik dan berbasis partisipasi masyarakat. Indikator terpenting dari kemajuan pariwisata, selain pemasukan negara melalui devisa, juga peningkatan kesejahteraan masyarakat di sekitar tempat wisata. Karena akan ironis apabila pendapatan devisa negara dari pariwisata menunjukkan angka yang tinggi, tetapi di sisi lain masyarakat di sekitarnya tidak ikut merasakan dampak positifnya (Hadiwijoyo, 2018: 87). Desa wisata mendorong terciptanya lapangan kerja baru bagi masyarakat setempat melalui pemanfaatan potensi desa oleh masyarakatnya yang dikemas sebagai daya tarik wisata. Selain itu, desa wisata mendorong masyarakat untuk menjaga kelestarian alam dan budaya demi mempertahankan minat wisatawan berkunjung ke desa wisata.

Dalam perkembangannya, tren desa wisata terus mengalami peningkatan. Berdasarkan 
data BPS, sampai dengan bulan Oktober 2018, terdapat 1.734 desa wisata di Indonesia. Desa wisata tersebut tersebar di seluruh pulau. Pulau Jawa dan Bali menempati posisi paling tinggi dengan jumlah 857 desa wisata. Kemudian diikuti Pulau Sumatera sebanyak 355 desa, Nusa Tenggara 189 desa, Kalimantan 117 desa, Pulau Sulawesi sebesar 119 desa, Papua 74 desa, dan Maluku 23 desa (Putra, 2019).

DIY yang menyandang predikat sebagai kota pariwisata juga tidak luput dari tren desa wisata. Bentuk kegiatan wisata berbasis budaya atau ekowisata banyak bermunculan, terutama di Kabupaten Sleman dan Gunung Kidul. Hal ini antara lain didukung oleh kepedulian masyarakat dalam menjaga kelestarian alam dan masih kentalnya aspek budaya yang mewarnai kehidupan masyarakatnya. Selain itu, arah pembangunan pariwisata DIY yang mengacu pada Peraturan Daerah DIY Nomor 1 Tahun 2012 tentang Rencana Induk Pembangunan Kepariwisataan DIY semakin memantapkan arah pengembangan pariwisata yang berwawasan budaya.

Di Kabupaten Sleman, jumlah desa wisata sudah mencapai 47 desa. Jumlah ini meningkat signifikan dibandingkan tahun sebelumnya 2018 yang masih berjumlah 31 desa. Dari 31 desa tersebut ada beberapa klasifikasi desa wisata, yakni desa wisata mandiri berdaya saing, mandiri, berkembang, tumbuh, dan desa wisata rintisan (Ermando, 2019). Perkembangan desa wisata menjadi salah satu indikator kemajuan sektor pariwisata. Partisipasi masyarakat merupakan ujung tombak dari kemajuan suatu wisata. Partisipasi aktif masyarakat akan memperkuat daya tawar dan dan daya saing desa wisata sebagai produk unggulan wisata. Oleh karena itu, dalam pengembangan suatu desa wisata, hal utama yang perlu mendapat perhatian dari pelaku wisata adalah partisipasi masyarakat setempat.

Berdasarkan uraian tersebut, permasalahan yang ingin diangkat dalam tulisan ini adalah bagaimana pengembangan Desa Wisata Pentingsari, Kabupaten Sleman dalam perspektif partisipasi masyarakat?

Penelitian pengembangan desa wisata dalam perspektif partisipasi masyarakat ini menggunakan pendekatan kualitatif deskriptif. Pendekatan kualitatif digunakan untuk mengungkapkan fenomena yang digali secara mendalam berdasarkan pandangan dan pengalaman masyarakat (Lewis, 2003). Sumber data dalam penelitian berupa data primer dan data sekunder. Data primer diperoleh dari wawancara mendalam dan pengamatan langsung untuk memperoleh informasidan pandangan masyarakat setempat sesuai dengan partisipasinya dalam pengembangan desa wisata. Sementara data sekunder meliputi data terkait pengembangan desa wisata dari perspektif partisipasi masyarakat yang telah dan sedang disusun oleh berbagai pihak. Hasil-hasil penelitian ataupun artikel di media massa turut memperkaya informasi yang dapat mendukung analisis penelitian.

Adapun teknik pengumpulan data dilakukan melalui observasi, wawancara (wawancara mendalam dan Focus Group Discussion/FGD), dan studi dokumentasi. Pengumpulan data di daerah melibatkan beberapa Satuan Kerja Perangkat Daerah/SKPD dan stakeholders lain yang terkait dengan masalah pengembangan desa wisata dan partisipasi masyarakat seperti Dinas Pariwisata Kabupaten Sleman, Dinas Pemberdayaan Masyarakat Desa Kabupaten Sleman, Kelompok Sadar Wisata Pentingsari, Kepala Desa Umbulharjo, dan Masyarakat Desa Wisata Pentingsari. Penelitian ini menggunakan teknik analisis data kualitatif di mana proses analisis data berlangsung sejak awal hingga akhir penelitian sehingga merupakan satu kesatuan yang simultan dengan proses lain (Moleong, 2002: 163). Adapun empat tahapan analisis data yang dilakukan meliputi pengumpulan data selama proses penelitian berlangsung, reduksi data, display data, dan terakhir adalah penarikan kesimpulan.

Penelitian dilakukan di Desa Wisata Pentingsari, Kabupaten Sleman pada tahun 2017. Desa ini menarik untuk dikaji karena selain pernah dijadikan percontohan desa wisata oleh Dinas Pariwisata DIY, Pentingsari juga mendapat penghargaan dari Komite Kode Etik Pariwisata Dunia (World Committee on Tourism Ethics - WCTE) sebagai desa wisata yang mampu menerapkan prinsip-prinsip Kode Etik Pariwisata Dunia, terutama pada poin penerapan upaya pemberdayaan masyarakat lokal pada 
tahun 2011. Selain itu, upaya pengembangan Pentingsari sebagai desa wisata menuntut keterlibatan masyarakat yang besar dalam setiap kegiatannya. Dalam hal ini, masyarakat tidak hanya menjadi objek tetapi juga subjek dalam pengembangan desa wisata. Hal ini berbeda dengan pengembangan sebuah daerah wisata yang pada umumnya meminggirkan peran masyarakat lokal. Hasil dari pengembangan daerah wisata biasanya hanya dinikmati oleh sebagian masyarakat yang mempunyai modal besar. Berawal dari hal tersebut, maka perlu dilakukan penelitian lebih lanjut mengenai pengembangan Desa Wisata Pentingsari dalam perspektif partisipasi masyarakat.

\section{Konsep Pengembangan Desa Wisata}

Edward Inskeep (1991: 166) mendefinisikan desa wisata sebagai bentuk pariwisata di mana sekelompok kecil wisatawan yang tinggal dalam suasana tradisional, biasanya di desa-desa yang terpencil dan belajar tentang kehidupan pedesaan dan lingkungan setempat. Dengan demikian, desa wisata mempunyai ciri khas tertentu yang menjadi daya tarik wisata. Desa wisata menawarkan suasana alami pedesaan beserta ciri khasnya yang tidak ditemukan di perkotaan. Sebagaimana pendapat Nuryanti (1991: 131) bahwa desa wisata merupakan bentuk integrasi atraksi, akomodasi, dan fasilitas pendukung yang disajikan dalam struktur kehidupan masyarakat yang menyatu dengan tata cara dan tradisi yang berlaku. Dari pendapat ini, beberapa komponen penting dalam desa wisata meliputi: (1) akomodasi, biasanya memanfaatkan tempat tinggal masyarakat lokal; dan (2) atraksi berupa kehidupan sehari-hari masyarakat dengan latar desa sehingga memungkinkan berintegrasinya wisatawan sebagai partisipan aktif misalnya kursus membatik atau menari (Nuryanti, 1991: 131).

Terkait dengan konsep pengembangan desa wisata, beberapa prinsip pengembangan desa wisata adalah pertama, tidak bertentangan dengan adat istiadat atau budaya masyarakat setempat. Pengembangan desa wisata harus memperhatikan aspek kehidupan sosial, budaya desa tersebut.
Kedua, pembangunan fisik ditujukan untuk meningkatkan kualitas lingkungan desa dengan tidak mengubah apa yang sudah ada di desa seperti sanitasi, penyediaan air bersih dan perbaikan jalan sehingga memudahkan akses wisatawan yang berkunjung ke desa. Ketiga, memperhatikan unsur keaslian desa. Pembangunan desa menuju desa wisata harus menonjolkan ciri khas suatu desa yang dapat menjadi daya tarik wisata. Desa dikemas sedemikian rupa sehingga memberikan nuansa alami pedesaan dan keaslian desa. Keempat, memberdayakan masyarakat desa wisata. Tujuan dari pengembangan desa wisata adalah meningkatkan kesejahteraan masyarakat setempat melalui partisipasi aktif masyarakat dalam semua kegiatannya. Keterlibatan masyarakat dapat berupa penyediaan jasa dan pelayanan wisata yang hasilnya akan meningkatkan pendapatan masyarakat setempat (Theresia et al., 2014: 88-89). Dengan demikian, masyarakat lokal merupakan pelaku utama dalam pengembangan desa wisata. Keberhasilan dari pengembangan desa wisata tergantung dari tingkat penerimaan dan dukungan dari masyarakat lokal. Kedudukan masyarakat lokal sejajar dengan pemerintah dan swasta sebagai salah satu pemangku kepentingan dalam pengembangan desa wisata seperti ditunjukkan dalam Bagan 1 berikut (Wearing \& Donald, 2001).

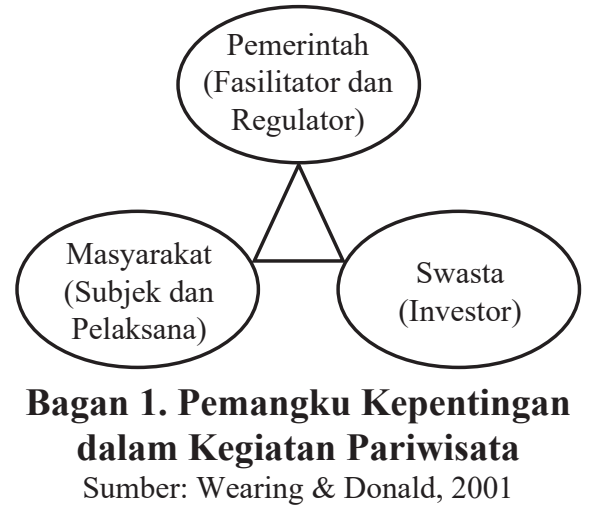

Bagan 1 menunjukkan pemangkukepentingan dalam kegiatan pariwisata adalah masyarakat, pemerintah, dan swasta. Ketiganya mempunyai peran dalam pengembangan pariwisata yang harus saling bersinergi. Partisipasi masyarakat merupakan komponen terpenting dalam upaya pengembangan pariwisata khususnya desa wisata. 


\section{Partisipasi Masyarakat}

Menurut Keith Davis dan Newstrom (1989: 232), partisipasi adalah keterlibatan mental dan emosi seseorang dalam situasi kelompok yang mendorong mereka untuk berkontribusi pada tujuan kelompok dan bersama-sama bertanggung jawab terhadap tujuan tersebut. Ide utamanya adalah keterlibatan, kontribusi dan tanggung jawab. Selanjutnya Isbandi (2007: 27) menyatakan bahwa partisipasi masyarakat merupakan keterlibatan masyarakat dalam proses pengidentifikasian masalah, potensi, dan kebutuhan masyarakat, pengambilan keputusan tentang alternatif solusi untuk menangani masalah, pelaksanaan upaya mengatasi masalah, dan proses evaluasi terhadap perubahan yang terjadi. Pendapat Isbandi diperkuat dengan konsep partisipasi Cohen dan Uphoff (1980: 33) yang menjelaskan partisipasi sebagai keterlibatan aktif masyarakat dalam proses pengambilan keputusan tentang apa yang akan dilakukan dan bagaimana cara kerjanya; keterlibatan masyarakat dalam pelaksanaan program melalui sumbangan sumber daya atau bekerja sama dalam suatu organisasi; serta keterlibatan masyarakat menikmati manfaat dari pembangunan serta dalam evaluasi pelaksanaan program. Dengan demikian, partisipasi masyarakat merupakan keterlibatan aktif masyarakat dalam semua proses pembangunan mulai dari perencanaan hingga evaluasi program. Dalam hal ini, masyarakat sebagai subjek, bukan objek pembangunan sehingga harus berperan aktif dalam semua prosesnya.

Selanjutnya Cohen dan Uphoff (1977: 8) membagi partisipasi masyarakat ke dalam empat tahapan, yaitu: pertama, tahap pengambilan keputusan. Dalam hal pengembangan desa wisata, masyarakat terlibat dalam rapatrapat untuk pengambilan keputusan terkait pengembangan desa wisata. Masyarakat yang akan menentukan hal-hal apa saja yang perlu dilakukan untuk pengembangan desa wisata. Ide dasar dari pengembangan desa wisata berasal dari masyarakat di sekitarnya karena masyarakat yang paling mengetahui potensi dan kebutuhannya. Selain itu, keterlibatan masyarakat penting untuk mendapatkan dukungan dari masyarakat dan memastikan bahwa hal yang akan diperoleh berkaitan dengan kebutuhan dan manfaat masyarakat setempat (Theresia et al., 2014: 7). Kedua, tahap implementasi. Wujud nyata partisipasi pada tahap ini digolongkan menjadi tiga, yaitu partisipasi dalam kontribusi sumber daya, partisipasi dalam bentuk keterlibatan dalam administrasi dan koordinasi, dan partisipasi dalam bentuk program yang dibuat masyarakat dan pemerintah. Wujud nyata partisipasi dalam tahap ini adalah sumbangan pemikiran, materi, maupun tindakan sebagai anggota dari suatu kegiatan pengembangan desa wisata. Ketiga, tahap menikmati hasil. Tahap ini dapat dijadikan indikator keberhasilan partisipasi masyarakat pada tahap pengambilan keputusan dan implementasi kegiatan pengembangan desa wisata. Sebagai subjek dari kegiatan pengembangan desa wisata, masyarakat seharusnya mendapatkan manfaat yang paling besar dari kegiatan tersebut baik dari segi material, sosial, dan personal. Selain itu, tahap ini akan merangsang kemauan masyarakat untuk selalu berpartisipasi dalam setiap program yang akan datang. Keempat, tahap evaluasi. Partisipasi masyarakat pada tahap ini merupakan umpan balik bagi perbaikan pelaksanaan kegiatan selanjutnya (Nurbaiti \& Bambang, 2017: 226). Bentuk partisipasi masyarakat dapat berupa mengumpulkan informasi terkait perkembangan kegiatan dan perilaku para pelaku kegiatan.

\section{Pengembangan Desa Wisata Pentingsari dalam Perspektif Partisipasi Masyarakat}

Pada tahun 2018, kunjungan wisatawan baik domestik maupun mancanegara ke Kabupaten Sleman mencapai 8.531.738 kunjungan. Pencapaian jumlah kunjungan wisatawan tersebut mengalami kenaikan sebanyak $18,06 \%$ dari kunjungan wisatawan tahun 2017 yang sebesar 7,22 juta kunjungan (Dispar Sleman, 2019). Jumlah ini juga melebihi target yang ditetapkan Dinas Pariwisata Sleman, yakni 8 juta kunjungan wisatawan. Para wisatawan terkonsentrasi pada beberapa wisata, di antaranya wisata budaya $(54,49 \%)$, wisata alam $(32,73 \%)$, dan wisata buatan manusia (12,79\%) (Dispar Sleman, 2019). Selain tingginya kunjungan wisatawan, pengelolaan pariwisata di Sleman juga mengantarkannya menjadi kabupaten dengan 
indeks pariwisata peringkat ke-4 di Indonesia. Pengelolaan pariwisata di Sleman lebih banyak diarahkan untuk tujuan pembelajaran seperti keberadaan desa-desa wisatanya.

Desa wisata menerapkan konsep pemberdayaan masyarakat. Karena itu, partisipasi masyarakat merupakan komponen terpenting dalam pengembangan desa wisata. Pentingsari termasuk salah satu desa wisata di Kabupaten Sleman. Secara geografis, bentuk Desa Wisata Pentingsari sangat unik seperti semenanjung di mana sebelah barat terdapat lembah yang sangat curam yaitu Kali Kuning dan sebelah selatan terdapat lembah yang berupa Goa Ledok/Ponteng dan Gondoran, sementara sebelah timur terdapat lembah yang curam yaitu Kali Pawon dan sebelah utara merupakan dataran yang dapat berhubungan langsung dengan tanah di sekeliling Kelurahan Umbulharjo sampai ke pelataran Gunung Merapi (Dinas Pariwisata DIY, 2014: 42).

Pentingsari masuk dalam kategori desa wisata mandiri berdaya saing. Kategori ini diberikan oleh Dinas Pariwisata Sleman pada tahun 2018 karena desa tersebut mampu menerapkan konsep pariwisata berbasis masyarakat. Dalam konsep ini, partisipasi masyarakat menjadi komponen utama dalam keberhasilan desa wisata. Partisipasi masyarakat dimulai dari tahap pengambilan keputusan, implementasi, menikmati hasil, dan evaluasi seperti ditunjukkan pada Bagan 2 berikut.

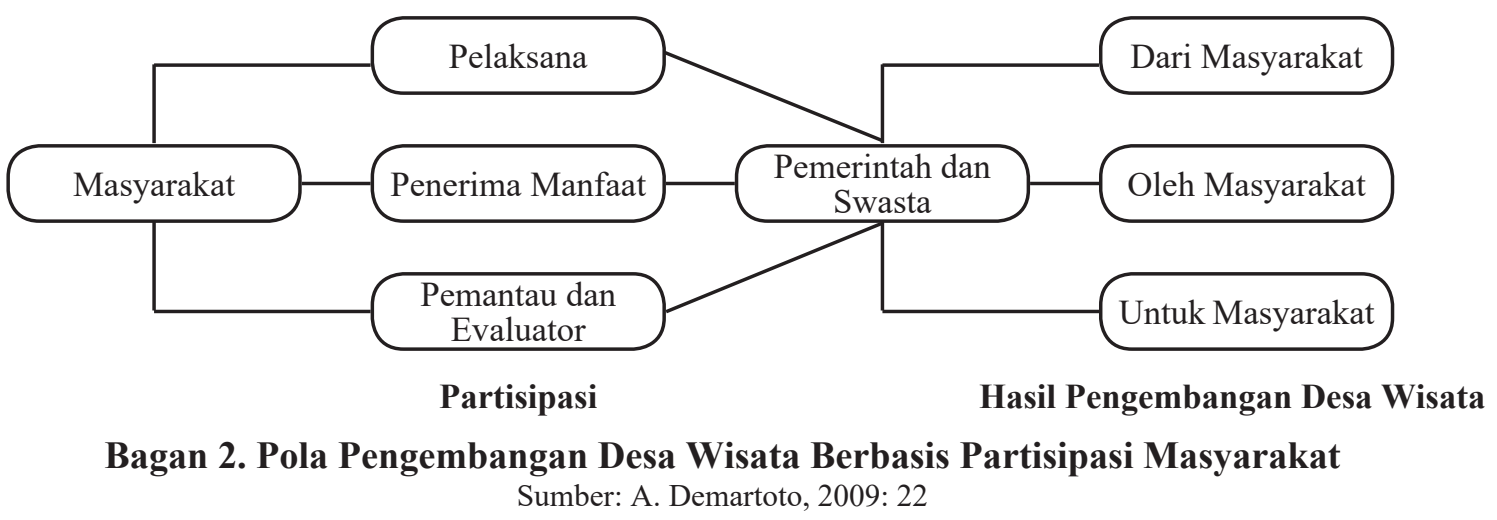

Partisipasi dalam pengambilan keputusan merupakan suatu proses dalam memilih alternatif yang diberikan oleh semua unsur masyarakat, lembaga-lembaga sosial dan lain-lain (Siagian, 1972:108). Pada tahap ini, keterlibatan masyarakat dalam proses pengambilan keputusan menjadi hal yang penting, karena masyarakat dituntut untuk menentukan arah dan strategi pembangunan sesuai dengan sikap dan budaya masyarakat setempat (Prayitno, 2009: 27). Hal ini juga sesuai dengan pendapat Davis (dalam Tangkilisan, 2005: 32) bahwa partisipasi masyarakat merupakan peristiwa psikologis yang mencakup keterlibatan mental dan emosional. Diharapkan masyarakat sebagai subjek pembangunan terlibat sepenuhnya dalam menggali, menentukan, dan merumuskan prioritas program pembangunan berdasarkan permasalahan, kebutuhan, dan potensi yang dimiliki. Adapun parameter yang digunakan untuk menentukan derajat partisipasi masyarakat adalah keterlibatannya dalam proses pengidentifikasi masalah, perumusan tujuan, dan pengambilan keputusan terkait pengembangan Desa Wisata Pentingsari.

Pada tahun 1990, Dusun Pentingsari termasuk salah satu dusun miskin di antara dusun-dusun yang ada di lereng Gunung Merapi. Dusun ini mempunyai tingkat perekonomian yang relatif rendah dan kehidupan masyarakat yang masih sederhana. Kondisi geografis dusun cukup terpencil karena sulitnya akses ke wilayah sekitarnya. Demikian juga kondisi lahan kurang subur dengan luas wilayah 103 ha dengan komposisi lahan pekarangan, perkebunan, daerah aliran sungai dan sebagian kecil persawahan. Mata pencaharian masyarakat adalah petani, pegawai swasta, dan PNS dengan kepemilikan lahan yang cukup luas, namun hasil pertanian kurang dihargai di pasaran. Kondisi ini mengakibatkan tingkat perekonomian masyarakat rendah.

Seiring berjalannya waktu, beberapa masyarakat mulai menyadari bahwa mereka harus mengubah keadaan masyarakat. Kesadaran ini mendorong mereka untuk mulai mencari 
ide bagaimana membangun dusun dengan tetap mempertahankan tradisi dan kearifan lokal yang ada. Berbagai potensi alam dan keragaman budaya yang ada di Pentingsari akan memiliki nilai lebih apabila dijadikan suatu objek wisata. Masyarakat harus membuka diri dan membangun interaksi positif dengan dunia luar untuk dapat berkembang. Selanjutnya dipilih konsep desa wisata dengan latar belakang bahwa melalui desa wisata akan dapat mengakomodasi semua komponen masyarakat untuk aktif bergerak sebagai subjek dan bukan hanya objek.

Masyarakat perintis desa wisata kemudian melakukan sosialisasi terkait ide pembentukan desa wisata kepada seluruh masyarakat di Dusun Pentingsari. Sosialisasi awal ini penting dilakukan mengingat mayoritas masyarakat dusun bermata pencaharian sebagai petani dan PNS. Proses sosialisasi dilakukan melalui rembug dusun dengan memberikan pemahaman kepada masyarakat tentang konsep desa wisata dan berbagai dampak dari kegiatan wisata di dusun. Hasil penelitian menunjukkan bahwa masyarakat cukup antusias dalam setiap pertemuan dusun. Semua elemen masyarakat selalu hadir dalam kegiatan rembug dusun yang membahas rencana pembentukan desa wisata tersebut seperti perwakilan RT, RW, pamong desa, BPD, dan beberapa perwakilan kepala keluarga. Dalam kegiatan tersebut, masyarakat diberikan kesempatan untuk memberikan ide dan saran terkait pembentukan desa wisata karena masyarakat yang paling mengetahui potensi dan kebutuhannya. Selain itu, masyarakat nantinya akan menjadi pelaku kegiatan wisata sehingga semaksimal mungkin arah pengembangan desa wisata disesuaikan dengan kebutuhan dan potensi yang dimiliki masyarakat.

Mengawali kegiatan bukan hal yang mudah karena butuh modal materi yang cukup, tekad dan keinginan yang besar. Selain itu, mengubah budaya petani menjadi penyedia jasa wisata cukup sulit dilakukan. Selama proses sosialisasi, tidak semua masyarakat menerima secara langsung tujuan dari sosialisasi. Karena itu, masyarakat perintis desa wisata berupaya melakukan pendekatan secara terus menerus baik secara personal maupun dalam pertemuan resmi untuk memberikan pemahaman dan meyakinkan masyarakat tersebut bahwa tujuan dari pembentukan desa wisata adalah untuk peningkatan kesejahteraan masyarakat dusun. Dengan semangat yang kuat dan dukungan dari pemerintah desa, akhirnya dicapai kesepakatan untuk menjadikan Pentingsari sebagai desa wisata. Perwakilan desa kemudian mengajukan gagasan desa wisata hasil kesepakatan masyarakat Pentingsari ke pemerintah daerah melalui Dinas Pariwisata Kabupaten Sleman. Dalam hal ini, pemerintah daerah diharapkan dapat memfasilitasi dan memberikan akses terhadap kegiatan wisata di Pentingsari.

Selanjutnya Dinas Pariwisata serta dinas terkait memberikan pelatihan-pelatihan kepada masyarakat sebagai bentuk dukungannya terhadap rencana pembentukan Desa Wisata Pentingsari. Pelatihan bertujuan untuk meningkatkan pengetahuan masyarakat seputar desa wisata sebagai bentuk persiapan dalam membangun sebuah desa wisata. Selain mengikuti pelatihan, masyarakat Pentingsari juga mulai mempersiapkan sarana dan prasarana pendukung desa wisata seperti menyediakan homestay, membangun area outbond, menyediakan lapangan parkir, perbaikan akses menuju desa wisata, dan segala bentuk dukungan terhadap desa wisata.

Pada tanggal 15 April 2008 Pentingsari dikukuhkan sebagai desa wisata oleh Pemerintah Kabupaten Sleman. Dalam hal ini, masyarakat yang kemudian merencanakan, melaksanakan, dan mengawasi semua pembangunan yang dilakukan dari, oleh, dan untuk masyarakat sendiri. Pelibatan masyarakat akan membuat masyarakat merasa memiliki desa wisata dan selanjutnya bertanggung jawab terhadap keberlanjutan desa wisata. Keterlibatan masyarakat yang dilakukan sejak awal menjadi salah satu faktor yang membuat partisipasi masyarakat dapat berjalan pada tahap selanjutnya. Seperti yang dikatakan Cornwal bahwa partisipasi masyarakat yang dilakukan sejak awal perencanaan dapat meningkatkan kemungkinan partisipasi berjalan dengan baik pada selanjutnya karena pelibatan masyarakat sejak awal akan meningkatkan tingkat tanggung jawabnya terhadap program tersebut (Cornwal, 2008). Partisipasi masyarakat juga dapat meningkatkan daya tawar masyarakat sehingga posisinya sejajar dengan pemerintah 
maupun swasta. Dengan demikian, masyarakat mempunyai power untuk mengontrol kebijakan pemerintah agar benar-benar sesuai dengan potensi dan kebutuhan masyarakat.

Selanjutnya, partisipasi masyarakat diwadahi dalam suatu kelompok yang disebut Kelompok Sadar Wisata (Pokdarwis). Pokdarwis menjadi salah satu lembaga yang mengelola kegiatan pariwisata di tingkat desa. Karena Pentingsari termasuk salah satu yang ada di Desa Umbulharjo, maka pokdarwisnya masih tergabung dengan pokdarwis Desa Umbulharjo, yakni Pokdarwis Maju Raharjo. Pokdarwis Maju Raharjo membawahi 9 dusun, yang semuanya dipersiapkan menjadi desa wisata dengan produk wisata yang berbeda seperti desa wisata, volcano tour, pondok wisata dan perkemahan, kuliner, serta pertanian dan home industry. Pentingsari sendiri dikembangkan menjadi desa wisata dengan berbagai ciri khas yang dimiliki.

Pokdarwis Maju Raharjo mempunyai struktur organisasi yang terdiri dari pengurus inti dan beberapa koordinator bidang, yaitu kegiatan, pembangunan, homestay, kesenian, konsumsi, cinderamata atau produk kreatif masyarakat, usaha kreatif, marketing atau komunikasi media sosial, keamanan, dan humas. Untuk lebih jelasnya akan ditunjukkan pada Bagan 3 berikut.

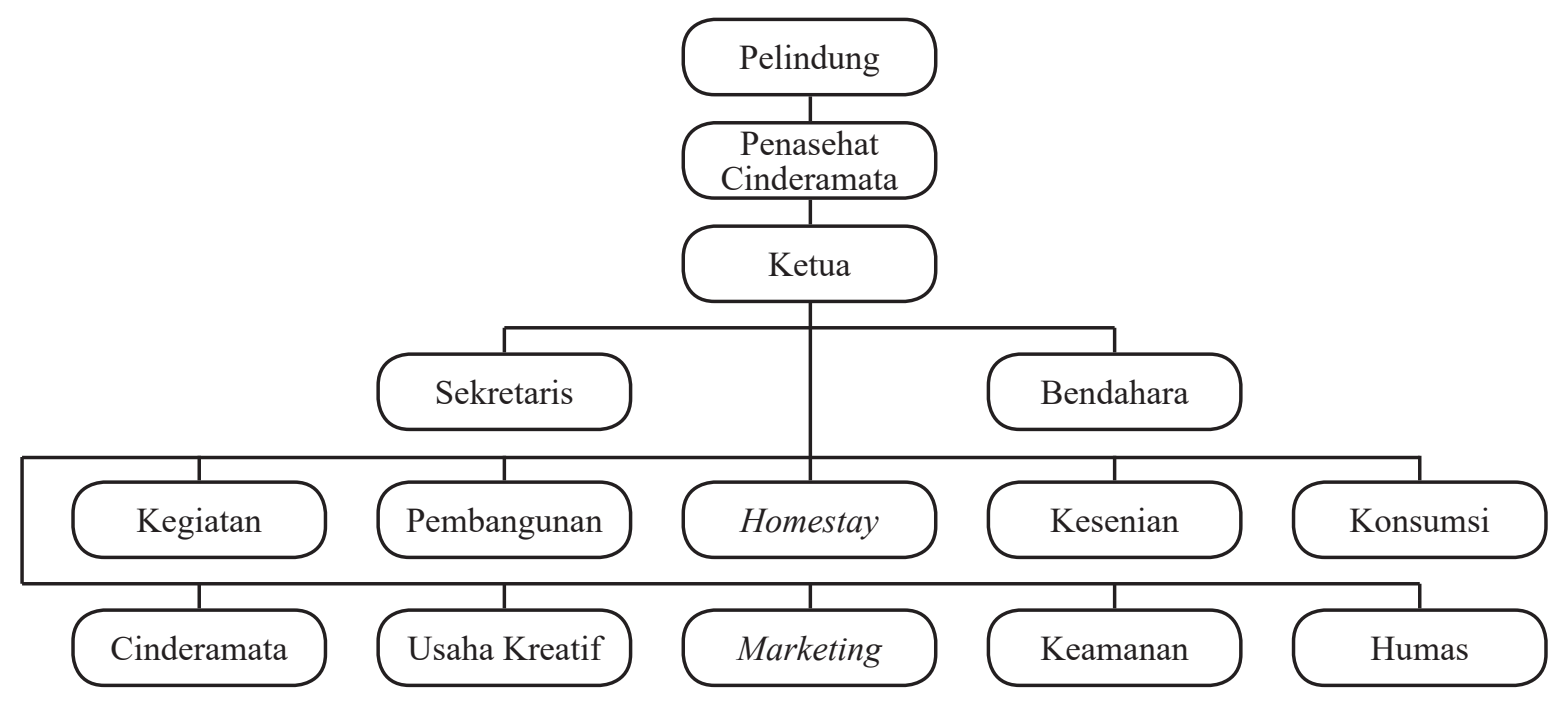

Bagan 3. Struktur Organisasi Pokdarwis Maju Raharjo

Sumber: Hasil Wawancara dengan Pokdarwis, 17 Oktober 2019

Pokdarwis dibentuk dari dan untuk masyarakat desa sehingga seluruh anggota pokdarwis adalah masyarakat Desa Pentingsari. Dalam pelaksanaanya, ketua pokdarwis membawahi langsung koordinator dan bendahara serta sekretaris. Mereka selalu berkoordinasi dan mengadakan pertemuan rutin setiap minggu sekali untuk mendiskusikan perkembangan desa wisata dan melakukan evaluasi kegiatan desa wisata yang telah dilakukan sekaligus merencanakan kegiatan yang perlu dilakukan untuk kemajuan Desa Wisata Pentingsari. Dengan adanya pokdarwis, maka terjadi sinergi yang terarah antarpengelola desa wisata baik dalam hal perencanaan, pengambilan keputusan, pelaksanaan kegiatan maupun evaluasi terkait pengembangan desa wisata. Semua pengelola desa wisata mempunyai pemahaman yang sama akan konsep pengembangan desa wisata yang melibatkan partisipasi masyarakat penuh. Pada gilirannya, hal tersebut akan mempercepat upaya pengembangan desa wisata agar mampu bersaing di industri pariwisata.

Setelah terbentuk desa wisata, diperlukan adanya situasi dan kondisi masyarakat yang memiliki pola berpikir sadar wisata. Penerapan sikap sadar wisata diharapkan akan mengembangkan pemahaman dan pengertian yang proporsional di antara berbagai pihak, sehingga pada gilirannya akan mendorong masyarakat untuk berpartisipasi secara penuh dalam pariwisata (Nursaid \& Armawi, 2016: 224). Di Pentingsari, pada awalnya, ada beberapa masyarakat yang tidak mau berpartisipasi dalam kegiatan wisata. Pokdarwis kemudian berupaya mengajak seluruh masyarakat dusun untuk mau 
terlibat dalam kegiatan wisata di Pentingsari. Sehingga sedikit demi sedikit masyarakat mau terlibat dalam kegiatan wisata.

Selanjutnya partisipasi masyarakat masuk dalam tahap implementasi. Parameter partisipasi masyarakat dalam tahap ini adalah keterlibatan dalam pengelolaan usaha wisata sesuai dengan kapasitas yang dimilikinya baik berupa sumber daya, administrasi, dan koordinasi dalam usaha desa wisata maupun kegiatan atau program yang telah disepakati bersama. Sejak awal, tujuan dari kegiatan wisata yang ada di Desa Wisata Pentingsari adalah meningkatkan taraf ekonomi masyarakat yang berbasis masyarakat, alam, budaya, dan pelestarian lingkungan. Dengan adanya kegiatan wisata ini, diharapkan memberikan nilai tambah pada kehidupan sosial dan budaya masyarakat desa, namun tetap mempertahankan kearifan lokal dan budaya masyarakat. Oleh karena itu, masyarakat desa mulai mengembangkan daya tarik wisata yang ada di dusun.

Masyarakat mengembangkan daya tarik utama yang dimiliki Pentingsari, yaitu kondisi alam dengan keanekaragaman vegetasi yang masih terjaga dengan baik dan kehidupan masyarakat khas pedesaan. Aktivitas kehidupan sehari-hari masyarakat ini kemudian dikemas dalam bentuk atraksi wisata berupa live in. Live in merupakan atraksi wisata di mana tamu akan mengikuti kegiatan tuan rumah dan kegiatan kelompok berbasiskan pertanian, petualangan, seni dan budaya maupun sosial kemasyarakatan, outbond, kemah dan tracking, membuat makanan tradisional, mengolah kopi, atraksi menari, gamelan, membatik, membuat wayang rumput, janur, dan atraksi pertanian.

Selain atraksi wisata live in, beberapa objek wisata alam juga mulai diperkenalkan seperti Pancuran Suci Sendangsari yang dipercaya oleh masyarakat Pentingsari dan sekitarnya bisa menyembuhkan berbagai penyakit dan membuat awet muda; batu dakon dan batu persembahan yang dipercaya memiliki nilai mistis sejak zaman penjajahan Belanda; Poteng sebagai tempat pertemuan Sungai Kuning dan Sungai Pawon yang dipercaya terdapat sebuah gua sebagai tempat singgahnya ular besar anak dari baruklinting (Dinas Pariwisata DIY, 2014:
43-45). Kondisi alam di Desa Wisata Pentingsari yang diapit oleh dua sungai (Sungai Pawon dan Sungai Kuning), juga cocok untuk dikembangkan sebagai wisata tracking.

Dalam setiap atraksi wisata tersebut, masyarakat mempunyai peran masing-masing sesuai dengan kompetensinya. Masyarakat terbagi ke dalam kelompok-kelompok kegiatan wisata sesuai dengan kapasitas yang dimiliki. Adapun kelompok tersebut terdiri dari penyedia homestay, pemandu wisata, pemandu atraksi kesenian, home industry makanan, kerajinan, dan konsumsi. Keterlibatan masyarakat lokal dalam tahap implementasi dalam arti pemanfaatan peluang terlihat besar. Hampir seluruh masyarakat dusun berpartisipasi dalam kegiatan wisata. Namun demikian, bentuk partisipasi masyarakat yang paling dominan adalah penyedia homestay. Homestay yang disediakan berada dalam satu rumah dengan rumah penduduk yang menyewakannya, sehingga unsur kesederhanaan sebagai ciri khas masyarakat pedesaan yang ditonjolkan untuk menarik wisatawan. Hasil dari penyewaan homestay menjadi milik masyarakat pemilik homestay, dikurangi Rp5.000 untuk kas Pokdarwis. Pokdarwis memberikan pinjaman dana bagi masyarakat yang rumahnya belum bisa dijadikan homestay sebesar Rp1 juta. Dana tersebut berasal dari Program Nasional Pemberdayaan Masyarakat (PNPM) Pariwisata yang digulirkan Kementerian Pariwisata beberapa tahun yang lalu. Masyarakat yang menerima pinjaman dana harus mengembalikannya dalam jangka waktu 6 bulan.

Saat ini lokasi homestay tersebar cukup merata. Keterlibatan masyarakat menjadi unsur yang penting mengingat letak homestay tidak sekadar mendekati objek atau atraksi wisata saja, namun diatur sesuai prinsip pemerataan oleh pengelola desa wisata. Dengan kata lain, sistem penyewaan homestay dilakukan secara bergiliran oleh Pokdarwis untuk menghindari kecemburuan sosial. Pada tahap ini, partisipasi masyarakat cukup besar. Masyarakat secara sukarela melakukan berbagai bentuk pengembangan untuk meningkatkan kualitas layanan homestay di Pentingsari. Tahun 2017, Desa Wisata Pentingsari memiliki 50 rumah masyarakat yang aktif dijadikan homestay. Dengan kapasitas rata- 
rata dua orang per kamar, secara keseluruhan homestay rumah warga dapat menampung maksimal 400 wisatawan. Tahun 2019, jumlah homestay bertambah menjadi 70 homestay. Kenaikan jumlah homestay diperkirakan karena peningkatan jumlah wisatawan ke Desa Wisata Pentingsari setiap tahunnya.

Selain kelompok homestay, masyarakat juga aktif terlibat dalam kelompok konsumsi. Tahun 2017, terdapat 7 kelompok konsumsi di mana masing-masing kelompok terdiri dari 40 orang. Mayoritas kelompok ini adalah wanita berusia 30-50 tahun. Kelompok konsumsi bertugas menyediakan konsumsi ketika ada rombongan wisatawan yang berkunjung ke desa dalam jumlah besar. Masing-masing kelompok bergiliran menyediakan makanan bagi wisatawan sesuai dengan jadwal yang telah disepakati bersama.

Partisipasi masyarakat juga terlihat dalam keterlibatannya dalam kelompok home industry, kelompok keamanan, kelompok atraksi seni, dan kelompok pemandu wisata. Tahun 2017, kelompok home industry berjumlah 6 kelompok yang masing-masing kelompok terdiri dari 12 orang, kelompok keamanan berjumlah 25 orang, kelompok atraksi seni sebanyak 20 orang, dan kelompok pemandu beranggotakan 47 orang.

Partisipasi masyarakat dalam masing-masing kelompok tersebut cukup besar. Sebagai pelaku utama wisata, masyarakat yang merencanakan, menciptakan, mengelola, dan mengembangkan daya tarik wisata bersama dalam suatu kelompokkelompok masyarakat yang memiliki kesamaan potensi.

Komunitas ini berada di bawah naungan Pokdarwis dan terintegrasi dengan pelaku wisata lain. Misalnya, kelompok atraksi kesenian. Kelompok ini harus mampu menampilkan kesenian yang menjadi ciri khas Pentingsari dengan berbagai kreativitasnya sehingga menjadi atraksi yang menarik wisatawan.

Adapun atraksi kesenian yang ada di Desa Wisata Pentingsari antara lain: Tari Jathilan sebagai tari penyambutan bagi rombongan wisatawan yang berkunjung ke Desa Wisata Pentingsari; cokekan atau karawitan, yakni seni memainkan alat musik gamelan; kegiatan belajar menari dan membatik; kegiatan membuat kerajinan tangan dari janur dan kerajinan wayang menggunakan bahan baku rumput yang disebut mendhong; kegiatan ronda malam dan bakti sosial; serta kendhuri, yakni acara selamatan mulai dari proses sebelum mengandung, melahirkan hingga prosesi selamatan untuk warga yang meninggal dunia.

Kemudian kelompok pemandu wisata yang bertugas mendampingi wisatawan mengunjungi objek wisata yang ada, dan kegiatan yang bersentuhan langsung dengan alam seperti outbond dan tracking, menanam padi di sawah serta membuat apotek hidup. Kegiatan ini mendapat dukungan penuh dari masyarakat Pentingsari. Terbukti masyarakat memberikan sumbangan tempat, waktu, dan tenaga untuk melayani wisatawan.

Dalam kegiatan pertanian, masyarakat menyediakan sebuah joglo yang berisi ruang pertemuan dan tanaman-tanaman herbal di sekitarnya. Di joglo ini wisatawan dapat melakukan diskusi untuk menggali informasi seputar tanaman herbal. Tanaman herbal juga dijual oleh masyarakat sebagai cinderamata.

Kemudian masyarakat juga menyediakan rumah produksi jamur tiram dan jamur kuping untuk dikunjungi wisatawan sekaligus memperlihatkan kepada wisatawan cara pengolahan jamur dan perawatannya mulai dari kantong-kantong pembibitan hingga jamur yang telah matang dan siap dipanen.

Masyarakat yang mempunyai pengolahan Kopi Robusta Tunggaksemi juga dengan sukarela menyediakan tempatnya untuk dikunjungi wisatawan. Wisatawan dapat melihat langsung pengolahan kopi mulai dari pembibitan, perawatan, hingga pengolahan menjadi kopi bubuk yang siap untuk dikonsumsi.

Bentuk partisipasi masyarakat lain ditunjukkan dengan kesediaannya mengikuti berbagai pelatihan-pelatihan terkait pengembangan desa wisata baik yang diselenggarakan pemerintah, swasta, dan masyarakat. Dalam hal ini, pemerintah berperan sebagai fasilitator berbagai pelatihan untuk peningkatan kualitas sumber daya manusia pengelola desa wisata. Sementara swasta lebih berperan sebagai penyedia dana dalam mengembangkan desa wisata.

Tahun 2011, pengelola desa wisata mengikuti pelatihan Pokdarwis se-Provinsi 
Dearah Istimewa Yogyakarta yang bertempat di Desa Wisata Brayut, Pendowoharjo, Ngaglik, Sleman. Pelatihan ini diselenggarakan oleh Kementerian Kebudayaan dan Pariwisata (saat ini Kementerian Pariwisata) bekerja sama dengan Dinas Pariwisata Provinsi DIY. Tahun 2017, giliran pemandu wisata yang ikut kegiatan pembinaan pemandu wisata angkatan ketiga tepatnya tanggal 15-16 November 2017 dengan peserta 30 orang pemandu wisata berlisensi di Kabupaten Sleman. Pemandu wisata merupakan salah satu bagian penting dalam keberhasilan pengembangan pariwisata. Oleh karena itu peningkatan kompetensi pemandu wisata melalui pemberian tambahan informasi bagi pemandu wisata menjadi hal yang penting untuk dilaksanakan.

Kelompok kuliner desa wisata juga aktif mengikuti pelatihan. Mereka berupaya memajukan desa wisata melalui peningkatan kualitas penyediaan makanan. Balai Latihan Kerja Pembangunan mendukung hal ini dengan memberikan pelatihan pengolahan pangan lokal sehingga mempunyai nilai jual sebagai oleh-oleh. Kelompok kuliner sangat antusias mengikuti pelatihan ini karena mereka menyadari kuliner termasuk salah satu pendukung utama dalam kegiatan wisata. Terkait pemasaran, masyarakat aktif berkoordinasi dengan Dinas Pariwisata Kabupaten Sleman untuk mempromosikan paket wisata desa.

Dalam upaya untuk mengembangkan desa, pihak pengelola Desa Wisata Pentingsari menjalin kerja sama dengan pihak swasta. PT Bank Central Asia Tbk (BCA) melalui program Bakti BCA meresmikan Desa Wisata Pentingsari (Dewi Peri) sebagai salah satu desa wisata binaan BCA pada tahun 2015. BCA secara aktif melakukan pembinaan kepada masyarakat Desa Wisata Pentingsari terkait pengelolaan sarana prasarana dan SDM melalui penyelenggaraan berbagai pelatihan.

Pelatihan ini mencakup beberapa materi, antara lain industripariwisata dan pengelolaannya, layanan prima, kerja sama tim, dan pelatihan komunikasi. Peserta pelatihan difasilitasi untuk melakukan benchmarking layanan prima di sebuah hotel di Yogyakarta. Diharapkan melalui upaya tersebut dapat membuka peluang usaha dan menciptakan lapangan pekerjaan bagi masyarakat setempat.

Berbagai kegiatan yang dilakukan masyarakat tersebut merupakan bentuk partisipasi masyarakat dalam tahap implementasi. Keterlibatan langsung masyarakat dalam pengelolaan desa wisata akan menumbuhkan kesadaran pentingnya menjaga keberlanjutan desa wisata. Pada tahap ini, masyarakat bisa dikatakan sudah berpartisipasi melalui kontribusinya berupa sumber daya dalam berbagai usaha wisata sekaligus berkoordinasi dalam kelompoknya untuk menjalankan kegiatan wisata desa. Sementara dalam hal partisipasi administrasi, masyarakat juga dilibatkan dalam mengelola administrasi kegiatan desa wisata melalui Pokdarwis.

Hasil yang diperoleh dari bentuk partisipasi masyarakat yang telah dilakukan menunjukkan hasil yang signifikan. Dinas Pariwisata Sleman bahkan memberikan apresiasi berupa penetapan Desa Wisata Pentingsari sebagai embrio desa wisata di Sleman. Kini Desa Wisata Pentingsari telah dikenal banyak orang sehingga tidak pernah sepi pengunjung. Setiap bulan terdapat 400 wisatawan yang berkunjung, baik untuk menginap dengan mengambil paket wisata yang ditawarkan desa maupun sekadar berwisata ke objek wisata yang tersedia. Masyarakat Desa Wisata Pentingsari merasakan manfaat dari kegiatan wisata di desanya. Pada tahap ini, partisipasi masyarakat masuk ke dalam tahap penerima manfaat dari kegiatan wisata.

\section{Tabel 2. Jumlah Wisatawan Desa Wisata} Pentingsari, Tahun 2012-2016

\begin{tabular}{ccccc}
\hline \multirow{2}{*}{ Tahun } & \multicolumn{2}{c}{ Wisatawan } & \multirow{2}{*}{ Jumlah } & $\begin{array}{c}\text { Persen- } \\
\text { tase (\%) }\end{array}$ \\
\cline { 2 - 3 } & Mancanegara & Domestik & & 19,8 \\
\hline 2012 & 2.765 & 27.184 & 29.949 & 22,8 \\
2013 & 525 & 34.053 & 34.578 & 25.181 \\
2014 & 149 & 25.032 & $25.16,6$ \\
2015 & 149 & 29.036 & 29.185 & 19,3 \\
2016 & 330 & 32.178 & 32.508 & 25,5 \\
\hline
\end{tabular}

Sumber: Hasil Wawancara dengan Pokdarwis, 10 Oktober 2017

Tabel 2 menunjukkan jumlah wisatawan yang berkunjung ke Desa Wisata Pentingsari selama kurun waktu 5 tahun. Terjadi fluktuasi wisatawan setiap tahunnya seperti terlihat dalam Tabel 2. 
Tahun 2012 ke tahun 2013 jumlah pengunjung meningkat tajam dari 29.949 wisatawan menjadi 34.578 wisatawan. Hal ini diindikasikan karena masyarakat Pentingsari semakin inovatif dalam menyelenggarakan kegiatan wisata, sehingga semakin menarik minat wisatawan untuk berkunjung ke Pentingsari. Kunjungan wisatawan tersebut beragam. Mayoritas wisatawan mengambil paket live in untuk menikmati suasana kehidupan pedesaan yang ditawarkan. Tahun 2014, wisatawan yang berkunjung turun menjadi 25.181. Namun, tahun 2015 dan 2016, jumlah pengunjung kembali meningkat. Fluktuasi jumlah wisatawan yang berkunjung ke Pentingsari juga dipengaruhi kemampuan pengelola desa untuk melayani wisatawan. Prinsip yang dipegang oleh pengelola Desa Wisata Pentingsari adalah mempertahankan kualitas pelayanan sehingga tidak boleh menerima wisatawan dalam jumlah yang melebihi kemampuan desa.

Pada awal berdirinya, tahun 2008, omzet Desa Wisata Pentingsari masih 30 juta per tahun dari 127 kepala keluarga (KK). Hal ini disebabkan keterbatasan sumber daya manusia dan sarana prasarana pendukung wisata. Saat itu baru terdapat 10 homestay, lapangan seadanya sebagai tempat berkemah, pemandu wisata juga masih terbatas dan jumlah wisatawan belum mencapai 1000 orang. Dengan omzet tersebut, Desa Wisata Pentingsari belum mampu mengandalkan kegiatan pariwisata untuk meningkatkan perekonomian masyarakat. Setelah dilakukan pendampingan dari berbagai pihak, tahun 2009 , omzet desa naik menjadi Rp250 juta per tahun dengan jumlah wisatawan mencapai 5000 orang per tahun.

Tahun 2010, Pentingsari mendapat bantuan dana dari Kementerian Pariwisata melalui program PNPM Mandiri Pariwisata. Bantuan ini mampu mempercepat upaya peningkatan sarana dan prasarana wisata sehingga tahun 2010, sehingga Pentingsari sudah mempunyai 40 rumah yang siap menjadi homestay, beraneka atraksi kesenian dan kuliner, serta jalan akses masuk desa telah siap. Dampaknya adalah pengunjung meningkat menjadi lebih 9000 wisatawan, mendekati target pengelola wisata, yakni 10.000 wisatawan. Dengan jumlah pengunjung tersebut, dipastikan omzet desa ikut naik.
Tabel 3. Penghasilan Desa Wisata Pentingsari, Tahun 2008-2016

\begin{tabular}{cc}
\hline Tahun & Penghasilan per Tahun (Rupiah) \\
\hline 2008 & 30 juta \\
2009 & 250 juta \\
2010 & Erupsi Gunung Merapi \\
2011 & 1 miliar \\
2012 & 1 miliar \\
2013 & 1 miliar \\
2014 & 1 miliar \\
2015 & 2,5 miliar \\
2016 & 2,5 miliar \\
\hline
\end{tabular}

Sumber: Hasil Wawancara dengan Pokdarwis, 17 Oktober 2019

Namun demikian, terjadinya erupsi Gunung Merapi pada bulan Oktober 2010, mengganggu kegiatan pariwisata di desa. Bahkan kegiatan pariwisata desa terhenti saat itu. Desa wisata yang sudah mulai menjadi andalan bagi perekonomian masyarakat menghilang. Sebanyak 25 ha sawah di DAS Kali Kuning hilang, dua jembatan putus sehingga akses menuju desa tertutup. Dengan semangat dan modal pantang menyerah, masyarakat desa berusaha mengembalikan kondisi desa. Dibutuhkan waktu lebih dari 6 bulan untuk rehabilitasi dan rekonstruksi desa wisata sekaligus mengembalikan kepercayaan masyarakat luas bahwa Desa Wisata Pentingsari telah pulih.

Tahun 2011 menjadi titik balik kebangkitan desa. Bantuan dana dari Program PNPM Mandiri Pariwisata tahap kedua sebesar Rp65 juta sangat membantu upaya pengelola desa wisata untuk merehabilitasi sarana dan prasarana wisata desa yang rusak akibat erupsi. Selain itu, kerja sama dengan pihak swasta, yakni Bank BCA dan berbagai lembaga pengabdian masyarakat di perguruan tinggi untuk peningkatan sarana dan prasarana desa, pengembangan kapasitas masyarakat, dan pengembangan ekonomi produktif mampu mengembalikan semangat masyarakat setempat untuk melakukan kegiatan wisata di desanya. Hasilnya, jumlah kunjungan wisata kembali meningkat.

Tahun 2011 pengunjung mencapai 20.000 wisatawan dan meningkat menjadi lebih dari 30.000 wisatawan pada tahun 2012. Peningkatan jumlah pengunjung berdampak pada omzet 
desa. Sepanjang tahun 2011, omzet Pentingsari meningkat tajam menjadi Rp1 miliar per tahun atau sekitar Rp100juta per bulan. Angka ini terus bertahan hingga tahun 2014.

Tahun 2014, pengelola Desa Wisata Pentingsari kembali mendapatkan dana pembinaan dan pelatihan dari BCA. Dari pelatihan tersebut, masyarakat memperbaiki standar homestay. Selain itu, pihak BCA juga memberikan pelatihan seputar pemasaran sehingga Pentingsari lebih dikenal masyarakat hingga mancanegara. Dampaknya, tahun 2015, omzet Pentingsari kembali meningkat. Dengan 55 unit homestay atau 150 kamar yang ada saat itu dan segala atraksi kesenian dan budaya yang ditampilkan, Pentingsari mampu mencapai omzet hingga Rp2,5 miliar atau sekitar Rp200 juta per bulan. Sampai tahun 2017, omzet Desa Wisata Pentingsari masih Rp2,5 miliar per tahun. Prinsip yang dipegang pengelola desa adalah kualitas pelayanan wisatawan sehingga pengelola desa wisata tidak mau menerima wisatawan dengan jumlah yang melebihi kapasitas pengelola desa wisata.

Dengan jumlah penduduk 390 jiwa pada tahun 2018, Desa Wisata Pentingsari mampu meningkatkan perekonomian masyarakat melalui berbagai kelompok yang terlibat meliputi kelompok homestay $(60 \mathrm{KK} / 100$ orang), kelompok konsumsi (8 kelompok/50 orang), kelompok home industry (6 kelompok/12 orang), kelompok pemandu (30 orang), kelompok atraksi seni (50 orang), dan kelompok keamanan (25 orang) (Hasil Wawancara dengan Pokdarwis, 17 Oktober 2019.).

Satu hal penting yang perlu digarisbawahi adalah penghasilan Pentingsari tersebut tidak keluar dari desa. Penghasilan tersebut didistribusikan kepada masyarakat Desa Wisata Pentingsari. Pengelola desa wisata tidak pernah mengambil lebih dari $10 \%$ dari penghasilan total desa wisata. Uang tersebut juga tidak digunakan untuk gaji pengelola desa wisata, namun dikembalikan untuk pengembangan desa wisata dari sisi berbeda. Dengan demikian, pengembangan desa wisata memberikan manfaat ekonomi baik secara langsung maupun tidak langsung kepada masyarakat setempat.
Adapun manfaat ekonomi secara langsung bagi masyarakat berupa tersedianya lapangan kerja baru seperti pemandu wisata, penyedia homestay, pemandu atraksi kesenian, tukang parkir, penyedia kuliner, dan usaha wisata lain. Ibu-ibu yang sebelumnya tidak bekerja, sekarang terlibat dalam kegiatan memasak untuk wisatawan. Selain itu, mereka juga mampu membuat keripik dan beberapa makanan olahan setelah mengikuti berbagai pelatihan pengolahan pangan lokal. Hal tersebut dapat menjadi sumber penghasilan tambahan bagi keluarganya.

Demikian juga pemuda-pemuda desa yang sebelumnya bekerja di luar desa, banyak yang kembali ke desa untuk ikut mengembangkan kegiatan wisata di desanya. Manfaat ekonomi secara tidak langsung diperoleh melalui desa, karena sebagian penghasilan dari penjualan tiket akan masuk ke kas desa untuk pembangunan desa. Pembangunan desa akan dirasakan dampaknya bagi seluruh masyarakat Pentingsari meskipun belum semua masyarakat berpartisipasi dalam pengelolaan desa wisata.

Pengembangan Desa Wisata Pentingsari juga mendukung aktivitas sehari-hari masyarakat, dengan adanya perbaikan kondisi jalan di sepanjang Pentingsari. Kondisi fisik jalan yang bagus selain memudahkan wisatawan dalam mengunjungi objek wisata, juga mempermudah masyarakat dalam melakukan aktivitasnya. Selain itu, lingkungan desa ikut lestari dengan adanya kegiatan wisata. Atraksi wisata pertanian yang diselaraskan dengan budaya desa secara tidak langsung merupakan bentuk pelestarian lingkungan. Misalnya, bersih desa, jumat bersih, penanaman tanaman buah, hortikultura, dan tanaman keras lain.

Sementara dari segi sosial, salah satu informan mengatakan bahwa perkembangan Desa Wisata Pentingsari telah memengaruhi kedudukannya di masyarakat. Sebelum adanya desa wisata, informan hanya seorang petani biasa. Setelah terbentuk desa wisata, informan menjadi salah satu pengelola desa wisata yang tergabung dalam Pokdarwis. Hal ini menunjukkan keberadaan desa wisata dapat memengaruhi kedudukan sosial seseorang dalam masyarakat. Keberadaan desa wisata juga memengaruhi hubungan masyarakat 
Pentingsari. Banyaknya kegiatan dan pertemuan terkait desa wisata semakin mendekatkan hubungan masyarakat. Solidaritas antarwarga semakin kuat. Demikian juga jiwa gotong royong semakin terjalin di antara pengelola desa wisata maupun antarwarga Pentingsari.

Dari segi lingkungan, keberadaan desa wisata telah mengubah pola kehidupan masyarakat Pentingsari. Masyarakat kini lebih sadar lingkungan. Masyarakat berusaha memelihara dan melestarikan lingkungan di sekitarnya karena menyadari pentingnya lingkungan bersih dan sehat untuk kehidupan masyarakat dan kenyamanan wisatawan saat berkunjung ke desa wisata Pentingsari. Dengan demikian, dalam diri masyarakat telah tertanam konsep sadar wisata yang secara tidak langsung akan memotivasi masyarakat untuk menjadi tuan rumah yang baik dalam kegiatan wisata di desanya.

Dari beberapa manfaat yang telah dirasakan masyarakat Pentingsari, dapat disimpulkan bahwa partisipasi dalam tahap menikmati hasil dari pengembangan Desa Wisata Pentingsari sudah dirasakan oleh sebagian besar masyarakat Desa Wisata Pentingsari.

Tahap selanjutnya adalah partisipasi dalam evaluasi. Parameter partisipasi masyarakat dalam evaluasi adalah keterlibatan masyarakat dalam tim pengawasan berikut kewenangan yang dimiliki. Hasil penelitian menunjukkan bahwa keterlibatan masyarakat Pentingsari dalam melakukan pengawasan terhadap perkembangan desa wisatanya cukup besar.

Pokdarwis menyelenggarakan forum setiap tiga bulan sekali untuk mengevaluasi kegiatan yang sudah dilakukan selama kurun waktu tiga bulan. Forum ini dihadiri oleh seluruh pengelola desa wisata dan perangkat desa. Selain forum tiga bulanan, Pokdarwis juga mengadakan forum tahunan. Forum tahunan membahas rencana kegiatan wisata ke depannya, keuangan desa wisata, dan evaluasi kegiatan yang sudah dilakukan selama setahun.

Pokdarwis juga menjalin komunikasi dengan pengelola desa wisata lain melalui forum pengelola desa wisata tingkat kabupaten dan provinsi. Forum ini cakupannya lebih luas dan sebagai wadah untuk mengembangkan jaringan.
Setiap enam bulan sekali diselenggarakan pertemuan yang dihadiri oleh para pengelola desa wisata baik tingkat kabupaten maupun provinsi serta pemerintah daerah.

Keberadaan forum cukup bermanfaat bagi para pengelola desa. Di samping saling berbagi pengalaman, mereka juga banyak belajar dari pengelola desa lain untuk lebih memajukan desa wisatanya. Dalam forum ini juga dilakukan evaluasi kegiatan yang telah dilakukan selama enam bulan dan rencana ke depan sekaligus kendala yang dihadapi desa wisata. Sehingga pemerintah daerah setempat mengetahui permasalahan dan kebutuhan dari masing-masing desa untuk dicarikan solusi terbaik bagi kemajuan desa wisata.

\section{Penutup}

Perkembangan desa wisata menjadi salah satu indikator kemajuan sektor pariwisata. Partisipasi masyarakat merupakan ujung tombak dari kemajuan suatu wisata. Oleh karena itu, dalam pengembangan suatu desa wisata, hal utama yang perlu mendapat perhatian adalah partisipasi masyarakat.

Hasil penelitian menunjukkan bahwa partisipasi masyarakat Pentingsari dalam pengembangan desa wisata cukup besar. Pada tahap perencanaan dan pengambilan keputusan, sebagian besar masyarakat Pentingsari terlibat langsung dari awal perencanaan, sosialisasi ke masyarakat dan pemerintah setempat hingga pengambilan keputusan tentang pembentukan desa wisata. Partisipasi implementasi ditunjukkan dalam bentuk sumbangan pemikiran, materi, dan terlibat aktif dalam setiap kegiatan wisata. Pada tahap ini masyarakat secara sukarela melakukan berbagai bentuk pengembangan untuk meningkatkan kualitas layanan homestay di Pentingsari. Selain itu, masyarakat aktif terlibat dalam kelompok-kelompok usaha wisata lain seperti pemandu wisata, konsumsi, dan atraksi kesenian. Masyarakat juga bersedia mengikuti berbagai pelatihan terkait pengembangan desa wisata baik yang diselenggarakan pemerintah, swasta, dan masyarakat.

Tahap selanjutnya adalah partisipasi dalam menikmati hasil. Adanya kegiatan wisata di 
Pentingsari memberikan manfaat yang cukup besar bagi masyarakatnya baik secara ekonomi, sosial, budaya, dan lingkungan. Manfaat ekonomi secara langsung berupa tersedianya lapangan kerja baru dan perbaikan kondisi jalan di sepanjang desa yang mendukung aktivitas sehari-hari masyarakat. Sementara manfaat ekonomi secara tidak langsung dirasakan dari pembangunan desa menggunakan sebagian hasil penjualan tiket masuk wisata. Dari segi sosial, perkembangan Desa Wisata Pentingsari telah memengaruhi kedudukan sosial seseorang di masyarakat dan mempererat hubungan antarwarga dengan banyaknya kegiatan wisata. Dari segi lingkungan, keberadaan desa wisata telah mengubah pola pikir masyarakat Pentingsari untuk lebih peduli lingkungan. Karena lingkungan bersih dan sehat menjadi salah satu syarat bagi kemajuan suatu desa wisata.

Partisipasi evaluasi ditunjukkan dengan keterlibatan masyarakat Pentingsari dalam pertemuan rutin yang diselenggarakan setiap bulan sekali. Dalam pertemuan ini, pengelola desa wisata bersama masyarakat dan pemerintah desa melakukan evaluasi kegiatan yang telah dilakukan desa wisata dan menyusun rencana ke depan. Selanjutnya, setiap 6 bulan sekali diselenggarakan juga pertemuan dengan forum yang lebih luas, yakni antarpengelola desa wisata se-kabupaten Sleman yang dihadiri pemerintah daerah.

Berdasarkan uraian tersebut, penulis merekomendasikan beberapa hal terkait pengembangan desa wisata. Pertama, keterlibatan masyarakat menjadi kunci utama bagi kemajuan desa wisata. Karena itu, masyarakat Pentingsari yang belum berpartisipasi dalam kegiatan pengembangan desa wisata perlu digerakkan sehingga manfaat dari kegiatan wisata dapat dirasakan secara merata oleh seluruh masyarakat Pentingsari. Kedua, meskipun Desa Wisata Pentingsari masuk kategori desa wisata mandiri sehingga hasil akan kembali ke masyarakatnya, namun dukungan pemerintah daerah tetap diperlukan. Hal ini terkait kebijakan pariwisata yang akan diberlakukan di Kabupaten Sleman. Kebijakan pariwisata tersebut diharapkan mendukung ke arah kemajuan desa-desa wisata di Sleman.

\section{Daftar Pustaka}

Adi, I. R. (2007). Perencanaan Partisipatoris Berbasis Aset Komunitas: Dari Pemikiran Menuju Penerapan. Depok: FISIP UI Press.

BPS. (2019, Februari 1). Jumlah Kunjungan Wisman ke Indonesia Desember 2018 Mencapai 1,41 Juta Kunjungan. Retrieved from https://www. bps.go.id/pressrelease/2019/02/01/1543/jumlahkunjungan-wisman-ke-indonesia-desember2018-mencapai-1-41-juta-kunjungan.html, on 7 Mei 2019.

Cohen, J.M. \& Uphoff, N. T. (1977). Rural Development Participation: Concepts and Measures for Project Design, Implementation and Evaluation. New York: Cornell University, Center for International Studies.

Cohen, J.M. \& Uphoff, N.T. (1980). Participation's Place in Rural Development: Seeking Clarity Through Specify. World Development, 8, 213235.

Cornwal, A. (2008). Unpacking Participation: Models, Meanings and Practices. Jurnal Oxford University and Community Development, 43(3), 269-283.

Davis, K. \& Newstorm, J.W. (1989). Human Behavior at Work, Organizational Behavior (Eight Edition). New York: McGraw Hill Book Company.

Demartoto, A. (2009). Pengembangan Pariwisata Berbasis Masyarakat. Surakarta: Sebelas Maret University Press.

Dinas Pariwisata DIY. (2014). Laporan Akhir Kajian Pengembangan Desa Wisata DIY 2014. DIY: Dinas Pariwisata DIY.

Dispar Sleman. (2019, Februari 20). 8,53 Juta Wisatawan Kunjungi Sleman di 2018. Retrieved from https://pariwisata.slemankab. go.id/2019/02/20/853-juta-wisatawan-kunjungisleman-di-2018, on 14 Mei 2019.

Ermando, A. (2019, Maret 13). Bertambah Signifikan, Desa Wisata di Sleman Kini Berjumlah 47. Retrieved from https://jogja.tribunnews. com/2019/03/13/bertambah-signifikan-desawisata-di-sleman-kini-berjumlah-47, on $8 \mathrm{Mei}$ 2019.

Hadiwijoyo, S.S.(2018).Perencanaan Pengembangan Desa Wisata Berbasis Masyarakat. Yogyakarta: Suluh Media. 
Herawati, A., Purwaningsih, A., Pudianti, A., \& Surya, R.V. (2014). Rural Tourism Community Empowerment Based on Local Resources For Improving Community Welfare. Review of Integrative Business Research, 3(2), 88-100.

Inskeep, E. (1991). Tourism Planning: An Integrated and Sustainable Development Approach. New York: Van Nostrand Reinhold.

Lewis, J. (2003). Design Issues In Qualitative Research Practice: a Guide for Social Science Student Researcher. London: SAGE Publications.

Moleong, L. J. (2002). Metode Penelitian Kualitatif. Bandung: Remaja Rosdakarya.

Novaria, A. (2018, Oktober 24). Devisa Dari Pariwisata Terus Meningkat. Retrieved from https://mediaindonesia.com/read/detail/193013devisa-dari-pariwisata-terus-meningkat, on 7 Mei 2019.

Nurbaiti, S. R. \& Bambang, A. N. (2017). FaktorFaktor yang Memengaruhi Partisipasi Masyarakat dalam Pelaksanaan Program Corporate Social Responsibility (CSR). Proceeding Biology Education Conference, 14(1), 224-228.

Nursaid, A. \& Armawi, A. (2016). Peran Kelompok Batik Tulis Giriloyo Dalam Mendukung Ketahanan Ekonomi Keluarga (Studi Di Dusun Giriloyo, Desa Wukirsari, Kecamatan Imogiri, Kabupaten Bantul, Daerah Istimewa Yogyakarta). Jurnal Ketahanan Nasional, 22(2), 217-236.

Nuryanti, W. (1991). Heritage, Tourism, and Local Communities. Yogyakarta: UGM Press.

Parma, I P. G. (2010). Kontribusi Pariwisata Alternatif Dalam Kaitannya Dengan Kearifan Lokal dan Keberlangsungan Lingkungan Alam. Media Komunikasi FIS Universitas Pendidikan Ganesha, 9(2), 45-57.

Petriella, Y. (2019, Maret 18). Pemerintah Koreksi Target Devisa Pariwisata. Retrieved from https:// ekonomi.bisnis.com/read/20190318/12/901135/ pemerintah-koreksi-target-devisa-pariwisata, on 7 Mei 2019.

Prayitno, D., Pujoyono, W. \& Warsono, H. (2009). Analisis Rendahnya Partisipasi Masyarakat Pada Implementasi Program Wajib Belajar Sembilan Tahun (Studi Kasus di Distrik Semangga Kabupaten Merauke). Dialog JIAKP, 6(1), 1336.
Putra, A. D. (2018, Desember 10). Data BPS: Indonesia Miliki 1.734 Desa Wisata. Retrieved from https://www.merdeka.com/uang/data-bpsindonesia-miliki-1734-desa-wisata.html, on 7 Mei 2019.

Siagian, S. P. (1972). Administrasi Pembangunan. Jakarta: Penerbit Gunung Agung.

Tangkilisan, N. H. (2005). Manajemen Publik. Jakarta: PT. Grasindo.

Theresia, A., Andini, K. S., Nugraha P. G. P., \& Mardikanto, T. (2014). Pembangunan Berbasis Masyarakat. Bandung: Alfabeta.

Wearing, S.L.\&Donald, Mc.(2001). The Development of Community Based Tourism: Re-Thinking The Relationship Between Tour Operators and Development Agents as Intermediaries in Rural and Isolated Area Communities. Journal of Sustainable Tourism, 10(3), 191-206. 